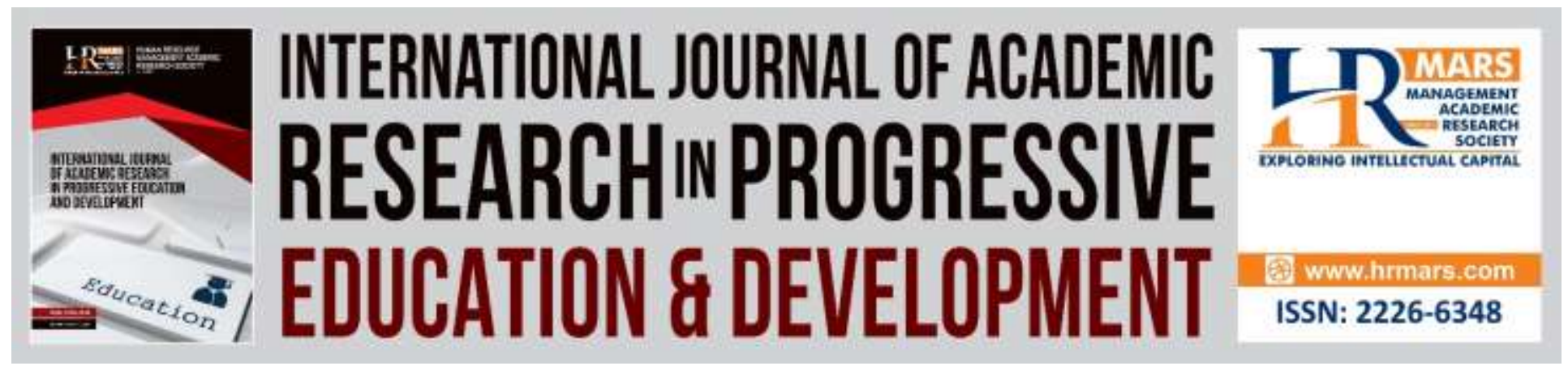

\title{
Academic Resilience among Malaysian Secondary School Students: A Confirmatory Factor Analysis
}

Rose Manisah Sulong, Nor Aniza Ahmad, Norlizah Che Hassan, Zaida Nor Zainudin, Maimunah Ismail

To Link this Article: http://dx.doi.org/10.6007/IJARPED/v8-i4/6618

DOI:10.6007/IJARPED/v8-i4/6618

Received: 10 October 2019, Revised: 29 October 2019, Accepted: 14 November 2019

Published Online: 30 November 2019

In-Text Citation: (Sulong et al, 2019)

To Cite this Article: Sulong, R. M., Ahmad, N. A., Hassan, N. C., Zainudin, Z. N., Ismail, I. (2019). Academic Resilience among Malaysian Secondary School Students: A Confirmatory Factor Analysis. International Journal of Academic Research in Progressive Education and Development, 8(4), 550-565.

Copyright: (C) 2019 The Author(s)

Published by Human Resource Management Academic Research Society (www.hrmars.com)

This article is published under the Creative Commons Attribution (CC BY 4.0) license. Anyone may reproduce, distribute, translate and create derivative works of this article (for both commercial and non-commercial purposes), subject to full attribution to the original publication and authors. The full terms of this license may be seen at: $\underline{\text { http://creativecommons.org/licences/by/4.0/legalcode }}$

Vol. 8(4) 2019, Pg. 550 - 565

http://hrmars.com/index.php/pages/detail/IJARPED JOURNAL HOMEPAGE

Full Terms \& Conditions of access and use can be found at http://hrmars.com/index.php/pages/detail/publication-ethics 


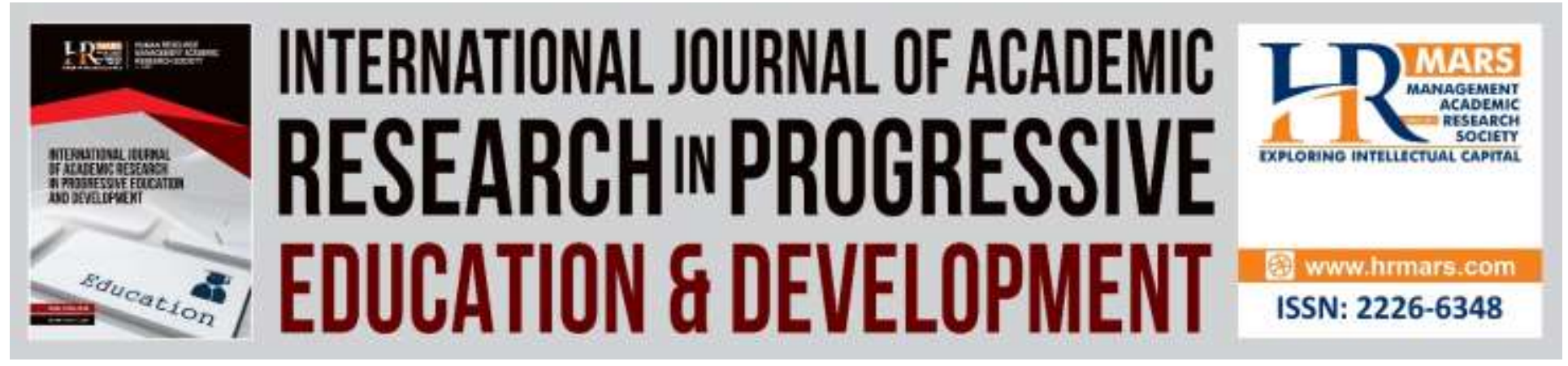

\title{
Academic Resilience among Malaysian Secondary School Students: A Confirmatory Factor Analysis
}

\author{
Rose Manisah Sulong, Nor Aniza Ahmad, Norlizah Che Hassan, \\ Zaida Nor Zainudin, Maimunah Ismail \\ Faculty of Educational Studies, Universiti Putra Malaysia
}

Email: nor_aniza@upm.edu.my

\begin{abstract}
Academic resilience refers to the ability of students to maintain motivation and achieve success in academics despite the presence of risk factors that put themselves at risk for failing and dropping out (Benard, 1991; Alva, 1991; Gonzalez \& Padilla, 1997; Finn \& Rock, 1997). Hence, studying and understanding the factors that make these students successful is important in helping them improve their academic performance. The purpose of the study is to validate the measurement model based on Resilience Theory (Benard, 1991). The proposed measurement model comprises three constructs, namely school external protective factors, resilience traits and academic achievement. This study involved a total of 315 secondary school students in the East Coast of Peninsular Malaysia. The findings show that the proposed measurement model fits the survey data. Therefore, through the actual data, the measurement model can be used to confirm the Resilience Theory.
\end{abstract}

Keywords: Confirmatory Factor Analysis, Measurement Model, Structural Equation Modelling, Academic Resilience, Education.

\section{Introduction}

Generally, students who are physically and psychologically stable are expected to excel academically compared to students with physical, mental and psychological problems (Achour \& Nor, 2014). Students who face psychological problems such as stress are more likely to face problems in their academic achievement (Yasin \& Dzulkifli, 2011; Emmanuel, 2014; Nachiappan et al., 2019). Students from low-income families are more likely to experience stress than their more capable peers (Jensen, 2009). In other words, the pressure of socioeconomic status is to be considered a risk factor (Masten, 2001) that will indirectly affect students' academic achievement. In fact, under normal circumstances, stress is very useful to students as it can help them build their resilience (Jensen, 2009); however, extreme stress can negatively affect students' academic achievement (Niemi \& Vainiomäki, 1999; Ofori, Lu, 2018). However, recent 
studies have shown that students from low socioeconomic backgrounds are still capable of good academic results and these students are said to be resilient (Demir \& Calendar, 2014).

Academic resilience refers to students' ability to maintain motivation to achieve success and succeed in academics despite the presence of risk factors that place them at risk of failure and dropping out of the education system (Benard, 1991; Alva, 1991; Gonzalez \& Padilla, 1997; Finn \& Rock, 1997). Academic resilience is a dynamic process of development that involves protective factor qualities, namely external and internal protective factors or resilience traits that play an important role in contributing to academic adjustment and success (Luthar, Cicchetti, \& Becker, 2000; Gizir \& Aydin, 2009 ). This is because protective factors can act as a buffer to compensate for the situation when a student is under stress (Werner, 2000).

There are many protective factors that can influence students' academic success in school. Resilience studies are important in bridging the academic achievement gap because all students actually have the ability to learn and succeed through nurturing of resilience (Benard, 2004). In fact, educators have long emphasized the importance of individual resilience for a student to be successful in life (Note, Soresi, Zimmerman, 2004). However, based on the literature review and resilience theory, school external protective factors and internal protective factors or resilience traits are seen as significant factors in influencing academic achievement among students on the East Coast of Peninsular Malaysia. To support the view of the literature, factor validation analysis was used to help the researcher test the theoretical relationship between latent variables such as external protective factors, resilience traits, and academic achievement (Bryant and Yarnold, 1995; Jackson, Gillaspy, and Purc- Stephenson, 2009; Schreiber, Nora, Stage, Barlow, and King, 2006). Hence, this study aimed to validate the proposed measurement model which consists of external protective factors, resilience traits and academic achievement.

\section{Literature Review}

Resilience theory is the work of Bernard Bonnie (1991). The theory states that if protective factors such as relationships with caring adults, high teacher expectations and student engagement are introduced and consistently practiced, students from small marginalized groups can overcome all obstacles and achieve academic success (Simon, 2012).

External protective factors are the social support environment and opportunities present at home, school, community and peer groups in the form of caring relationships, high expectations and encouragement to engage in meaningful activities (Jowkar, Kojuri, Kohoulat, \& Hayat, 2014). Caring relationships are defined as supportive relationships in student life that exemplify and support healthy development and well-being (California Department of Education \& WestEd, 2008). High expectations are defined as consistent communication through direct or indirect messages that students can succeed (California Department of Education \& WestEd, 2008). Meanwhile, meaningful engagement means students' engagement in relevant activities to experience responsibility and contribute something (California Department of Education \& WestEd, 2008). 
Benard's model suggests that these protective factors exist in families, schools, and communities where developmental needs of an individual such as safety, love, belonging, respect, power, challenge, skills, and meaning are met (Banatao, 2011). Caring relationships from adults fulfill the needs for safety, love, belonging and respect for students who face a variety of risk factors that can lead them to psychological or developmental problems (Benard, 1991). These environmental factors will influence the students, enabling them to develop self-efficacy, goals and various other traits that make them resilient. Interactions between external protective factors and resilience traits can contribute to positive academic, social and health outcomes and thus reduce involvement in risky behaviors (California Department of Education \& WestEd, 2008). In conclusion, the higher the external protective factors and resilience trait, the lower the probability of risky behavior occurring and the higher the academic achievement in schools (WestEd, 2014).

\section{Constructs of the Study}

This study focused on three main constructs, namely school external factors, resilience traits and academic achievement. External protective factors are positive action strategies that help build students' resilience including caring, high expectations and providing opportunity for meaningful participation and social support to exist in one of the students' environments, namely school (Benard, 1991; Jennings, 2003). According to Benard (1991), resilient students usually have four traits of resilience, namely social competence, problem solving skills, autonomy and having future goals and orientations. Table 1 shows the description of each construct and sub construct of the study.

Table 1. Construct and Sub Construct Description

\begin{tabular}{|c|c|c|}
\hline Construct & Sub Construct & Description \\
\hline \multirow{4}{*}{$\begin{array}{l}\text { School } \\
\text { External } \\
\text { Protective } \\
\text { Factors }\end{array}$} & Caring relationship & $\begin{array}{l}\text { Caring refers to the support of unconditional love } \\
\text { (Benard, 1991). }\end{array}$ \\
\hline & High Expectation & $\begin{array}{l}\text { High expectations refer to the consistent belief } \\
\text { that students can be successful in academics and } \\
\text { these hopes and expectations are clearly } \\
\text { communicated to the students (Benard, 1991). }\end{array}$ \\
\hline & $\begin{array}{l}\text { Meaningful } \\
\text { Participation }\end{array}$ & $\begin{array}{l}\text { The opportunity to contribute is to allow } \\
\text { students to actively participate in school and this } \\
\text { helps to develop autonomy, self-control and } \\
\text { leadership attitude in a student (Benard, 2004). }\end{array}$ \\
\hline & $\begin{array}{l}\text { Cooperation and } \\
\text { Communication }\end{array}$ & $\begin{array}{l}\text { Social skills such as cooperation and } \\
\text { communication refer to the ability to be flexible } \\
\text { in communication, the ability to work and } \\
\text { exchange ideas and information effectively with }\end{array}$ \\
\hline
\end{tabular}


Vol. 8, No. 4, 2019, E-ISSN: 2226-6348 @ 2019 HRMARS

\begin{tabular}{|c|c|c|}
\hline Construct & Sub Construct & Description \\
\hline & & $\begin{array}{l}\text { others, and the ability to express feelings and } \\
\text { needs to others (Benard, 1991). }\end{array}$ \\
\hline & Empathy & $\begin{array}{l}\text { Empathy refers to understanding and concern for } \\
\text { the experiences and feelings of others, which are } \\
\text { considered essential to healthy development, as } \\
\text { well as being rooted in moral and mutual respect } \\
\text { (Benard, 1991). }\end{array}$ \\
\hline \multirow[t]{4}{*}{$\begin{array}{l}\text { Resilient } \\
\text { Traits }\end{array}$} & Problem Solving & $\begin{array}{l}\text { Problem solving involves the ability to plan, be a } \\
\text { reference, be able to think critically and } \\
\text { creatively with multiple perspectives before } \\
\text { making any decision or action (Benard, 1991). }\end{array}$ \\
\hline & Self-Efficacy & $\begin{array}{l}\text { Self-efficacy refers to the belief in one's ability } \\
\text { and believing that he or she has the power to } \\
\text { make a change (Benard, 1991). }\end{array}$ \\
\hline & Self-Awareness & $\begin{array}{l}\text { Self-awareness is knowing and understanding } \\
\text { oneself (Benard, 1991). }\end{array}$ \\
\hline & Aspiration and Goal & $\begin{array}{l}\text { Having aspirations and goals refers to having high } \\
\text { expectations and dreams for oneself (Benard, } \\
\text { 1991). }\end{array}$ \\
\hline
\end{tabular}

The literature review also shows that external protective factors and resilience traits play an important role in academic achievement among high school students. An example of a study conducted by Banatao (2011) that examined the relationship between school external factors and academic achievement among California school children revealed that school external factors have a positive relationship with student academic achievement. This study concludes that the higher the external protective factors, the higher the academic achievement of students. Sharkey, You and Schnoebelen (2008) studied the relationship between external protective factors and individual resilience involving a sample of 10,000 students from grades 7, 9 and 11 in the United States and found that school protective factors as measured through the dimensions of caring relationships by adults in school have a significant direct relationship with individual resilience measured through three dimensions of individual resilience, namely self-concept, interpersonal skills, and goals and aspirations. Similarly, Wasonga (2002) who studied the relationship between resilience development and academic achievement involving 424 students in grades 9 through 12 found that resilience traits contributed to academic achievement of both boys and girls. 


\section{Research Methods \\ Survey Instrument}

The instrument used for this study was a questionnaire consisting of 80 items that measured school external protective factors and resilience traits. Academic achievement was measured based on the grade attained for 10 subjects in the Form 3 Examination (PT3). The items for the questionnaire were adapted from previous studies and modified for use in this study. A total of six experts in education were involved in the validity process of the questionnaire. The questionnaire was measured on a 5-point Likert rating scale where 1 = very untrue, 2 = not true, 3 = quite true, 4 = true and 5 = very true about me. The questionnaire also went through the reliability testing process. A pilot study was conducted on 180 high school students with characteristics similar to the actual sample. The results of the pilot study showed that the questionnaire was highly reliable because the Cronbach Alpha value for the study's constructs (refer Table 2) was greater than .90. Hair et al. (2010) claim that if the Cronbach's Alfa coefficient of a questionnaire exceeds 0.70 , this indicates that the questionnaire has good reliability. Therefore, the questionnaire was ready for use in the field study without having to go through any amendment.

Table 2. Cronbach's Alpha Coefficient $(\alpha)$ for Study Construct

\begin{tabular}{llcc}
\hline Construct & Sub Construct & $\begin{array}{c}\text { No. of } \\
\text { item }\end{array}$ & $\begin{array}{c}\text { Cronbach's } \\
\text { Alpha } \\
\text { Coefficient }(\boldsymbol{\alpha})\end{array}$ \\
\hline School External Protective Factors & $\begin{array}{l}\text { Caring relationship } \\
\text { High Expectation }\end{array}$ & 8 & .920 \\
& Meaningful Participation & 5 & \\
\hline \multirow{5}{*}{ Resilient Traits } & Cooperation and & 8 & \\
& Communication & 9 & \\
& Empathy & 953 \\
& Problem Solving & 9 & \\
& Self-Efficacy & 7 & \\
& Self-Awareness & 13 & \\
& Aspiration and Goal & 8 & \\
\hline
\end{tabular}

\section{Data Collection}

The respondents were 315 students (16 years of age) who were randomly selected from secondary schools in the East Coast of Peninsular Malaysia. The questionnaire was administered with the help of school counselors during school hours after obtaining permission to conduct study from the Ministry of Education Malaysia, State Education Department, schools and the secondary school students involved.

\section{Data Analysis and Results}

The data were analyzed using Statistical Packages for Social Sciences (SPSS) software and Analysis of Moments Structure (AMOS) software version 22.0. Table 3 shows the frequency and percentage of respondents by gender. Of the 315 respondents, 163 (51.7\%) were female. 
Vol. 8, No. 4, 2019, E-ISSN: 2226-6348 @ 2019 HRMARS

Meanwhile, the remaining 152 (48.3\%) were male students. This shows that the difference between the number of female students and the number of male students is only 11 respondents. Table 3 also shows that all the respondents were 16 year olds. The same table also reported that all the respondents involved in this study were Malay students which is 315 (100\%) students.

Table 3. Profile of Respondents.

\begin{tabular}{|c|c|c|}
\hline Variable & Frequency & Percentage \\
\hline \multicolumn{3}{|l|}{ Gender } \\
\hline Male & 152 & $48.3 \%$ \\
\hline Female & 163 & $51.7 \%$ \\
\hline \multicolumn{3}{|l|}{ Age (year) } \\
\hline 16 & 315 & $100 \%$ \\
\hline \multicolumn{3}{|l|}{ Ethnicity } \\
\hline Malay & 315 & $100 \%$ \\
\hline
\end{tabular}

Structural equation modeling was used to evaluate and validate the proposed measurement model. In structural equation modeling, two analyzes are involved, namely (1) confirmatory factor analysis (CFA) or also known as the measurement model and (2) the structural model. The purpose of the CFA is to determine the construct validity of a measurement model and to determine whether a data set is compatible with the proposed measurement model (Byrne, 2010). CFA is a validation analysis technique driven by the theoretical relationship between observed variable and unobserved variable (Schreiber, Nora, Stage, Barlow, \& King, 2006). Through confirmatory factor analysis, items that do not match or fit the measurement model need to be dropped. The factor loading for each item should be greater than 0.50 , and if any item has a factor loading of less than 0.50 , the item should be considered to be dropped (Hair et al., 2010). In addition, as shown in Table 4, the value of fitness indices must also be in accordance with the criteria established for the index acceptance. The model is said to have a good fit if at least one of the fitness measurement indices representing each of the three categories reaches the acceptable level (Awang, 2012).

Table 4. Fitness Index Acceptance Criteria

\begin{tabular}{cccc}
\hline Category & Index Name & Acceptance Level & Source \\
\hline Absolute fit & RMSEA & $<0.08$ & Brown \& Cudeck (1993) \\
& GFI & Near to 0.90 & Schumacker \& Lomax (2010) \\
Incremental fit & TLI & $>0.90$ & Bentler \& Bonett (1980) \\
& CFI & $>0.90$ & Bentler (1990) \\
Parsimonious fit & $\chi^{2} / \mathrm{df}$ & $<2.0$ & Marsh \& Hocevar (1985)
\end{tabular}

RMSEA: Root Mean Squared Error of Approximation; GFI: Goodness of Fit Index; TLI: Tucker-Lewis Index; CFI: Comparative Fit Index; $\chi^{2}$ : Chi-Square; df: Degree of Freedom

Figure 1 shows the initial measurement model of this study. After examining the value of the fitness index, it was found that the measurement model had a weak index value, where some 
Vol. 8, No. 4, 2019, E-ISSN: 2226-6348 C 2019 HRMARS

values still did not meet the acceptance criteria. The weaknesses of the index values for the initial measurement model can be seen in Table 5. To improve the fitness of the initial CFA model, modification indices (M.I) were referred to identify items that needed to be dropped or to be correlated.

Table 5. Fitness Index Value for Initial Measurement Model

\begin{tabular}{ccccc}
\hline Category & Index Name & $\begin{array}{c}\text { Acceptance } \\
\text { Level }\end{array}$ & $\begin{array}{c}\text { Index } \\
\text { Value }\end{array}$ & Result \\
\hline Absolute fit & RMSEA & $<0.08$ & .056 & Achieved \\
& GFI & Near to 0.90 & .642 & Not achieved \\
Incremental fit & $\mathrm{TLI}$ & $>0.90$ & .739 & Not achieved \\
& $\mathrm{CFI}$ & $>0.90$ & .746 & Not achieved \\
Parsimonious fit & $\chi^{2} / \mathrm{df}$ & $<2.0$ & 2.012 & Not Achieved \\
\hline
\end{tabular}

RMSEA: Root Mean Squared Error of Approximation; GFI: Goodness of Fit Index; TLI: Tucker-Lewis Index; CFI: Comparative Fit Index; $\chi^{2}$ : Chi-Square; df: Degree of Freedom

After examining the factor loading and M.I was performed, a total of 12 items were dropped for the school external protective factor. The items were CR5 and CR8 which represented the sub construct of caring relationship, HE9, HE14, HE15, HE16 and HE17 which represented high expectations and MP18, MP20, MP21, MP25 and MP26 which represented meaningful participation opportunities. For resiliency traits, items CC1, CC2, CC3, CC5 and CC8 (representing cooperation and communication), EM9, EM13, EM14, EM16 and EM17 (representing empathy), PS18, PS19, PS20, PS24, PS25 and PS26 (representing problem solving), SE29, SE31, SE32 and SE33 (representing self-efficacy), SA34, SA35, SA36, SA37, SA38, SA39, SA40, SA42, SA43, SA45 and SA46 (representing self-awareness) and GA47, GA51, GA52, GA53 and GA54 (representing goals and aspirations) were dropped. Meanwhile, for academic achievement, seven subjects, namely English Language 1 (written), English Language 2 (oral), Life Skills, Geography, Mathematics, Sciences and History were dropped. 
INTERNATIONAL JOURNAL OF ACADEMIC RESEARCH IN PROGRESSIVE EDUCATION AND DEVELOPMENT

Vol. 8, No. 4, 2019, E-ISSN: 2226-6348 @ 2019 HRMARS

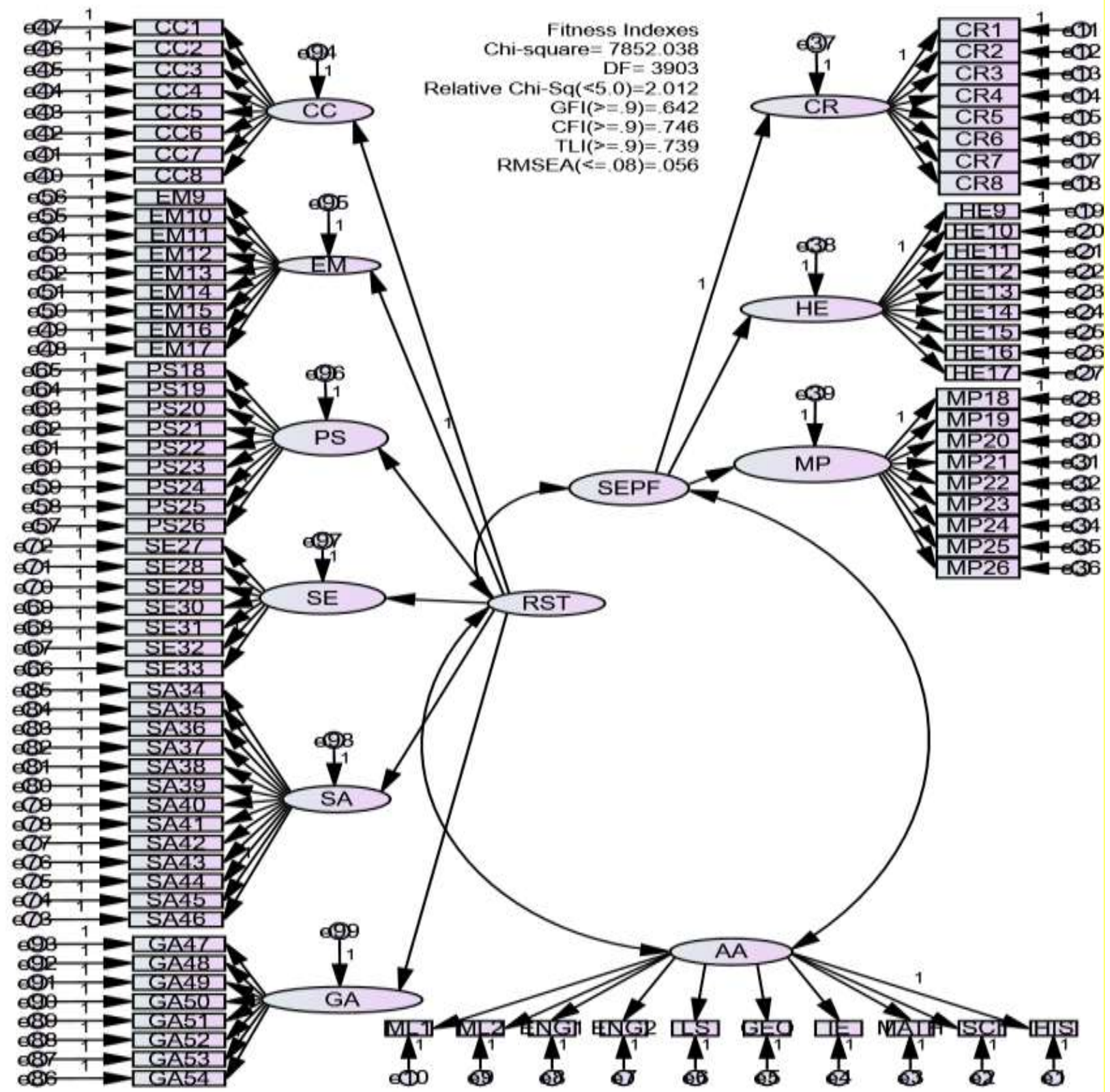

Figure 1. Initial Measurement Model

RST: Resilience Traits; CC: Cooperation and Communication; EM: Empathy; PS: Problem Solving; SE: Self- Efficacy; SA: Self Awareness; GA: Goals and Aspirations; SEPF: School External Protective Factor; CR: Caring Relationship; HE: High Expectation; MP: Meaningful Participation; AA: Academic Achievement; ML: Malay Language; ENG: English Language; LS: Life Skills; GEO: Geography; IE: Islamic Education; MATH: Mathematic; SCI: Science; HIS: History

As a result, the model of this study achieved sufficient fitness indices values through the modified measurement model as shown in Figure 2. Table 6 shows that all the fitness indices were 
INTERNATIONAL JOURNAL OF ACADEMIC RESEARCH IN PROGRESSIVE EDUCATION AND DEVELOPMENT

Vol. 8, No. 4, 2019, E-ISSN: 2226-6348 @ 2019 HRMARS

achieved with relative values of chi-square $(1.525<5.0)$, GFI $(0.867$ near to 0.90$)$, CFI $(0.937>$ $0.90)$, TLI (0.932>0.90), and RMSEA $(0.040<0.08)$.

Table 6. Fitness Index Value for Measurement Model after Modification

\begin{tabular}{ccccc}
\hline Category & Index Name & $\begin{array}{c}\text { Acceptance } \\
\text { Level }\end{array}$ & $\begin{array}{c}\text { Index } \\
\text { Value }\end{array}$ & Result \\
\hline Absolute fit & RMSEA & $<0.08$ & .040 & Achieved \\
& $\mathrm{GFI}$ & Near to 0.90 & .867 & Achieved \\
Incremental fit & $\mathrm{TLI}$ & $>0.90$ & .932 & Achieved \\
& $\mathrm{CFI}$ & $>0.90$ & .937 & Achieved \\
Parsimonious fit & $\chi^{2} / \mathrm{df}$ & $<2.0$ & 1.525 & Achieved \\
\hline
\end{tabular}

RMSEA: Root Mean Squared Error of Approximation; GFI: Goodness- of- Fit Index; TLI: TuckerLewis Index; CFI: Comparative Fit Index; $\chi^{2}$ : Chi-Square; df: Degree of Freedom

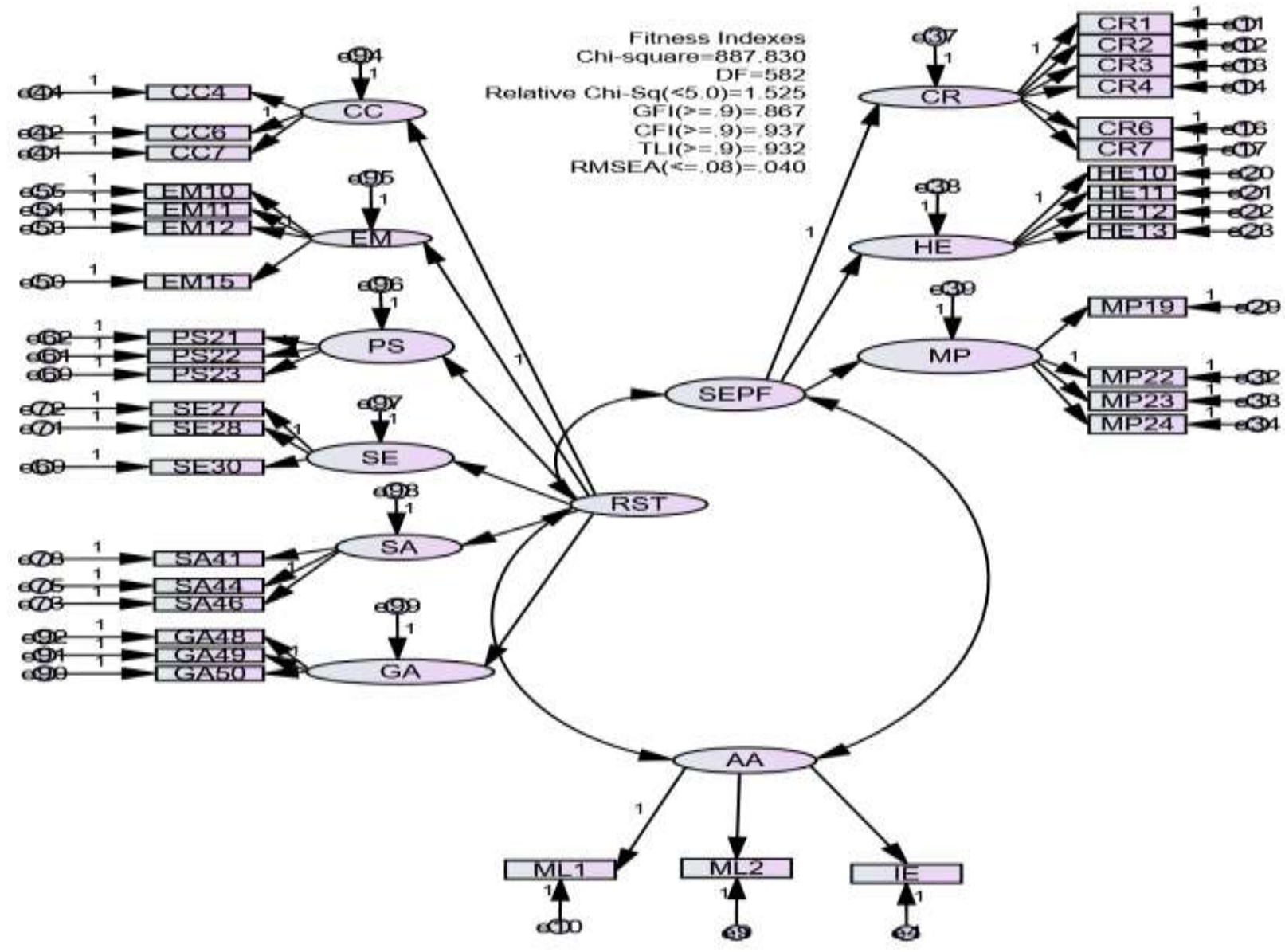

Figure 2. Measurement Model after Modification 
RST: Resilience Traits; CC: Cooperation and Communication; EM: Empathy; PS: Problem Solving; SE: Self- Efficacy; SA: Self Awareness; GA: Goals and Aspirations; SEPF: School External Protective Factor; CR: Caring Relationship; HE: High Expectation; MP: Meaningful Participation; AA: Academic Achievement; ML: Malay Language; ENG: English Language; LS: Life Skills; GEO: Geography; IE: Islamic Education; MATH: Mathematic; SCI: Science; HIS: History

The confirmatory factor analysis used can also evaluate the validity and reliability of the measurement model of latent constructs (Awang, 2015). Validity is very important in obtaining accurate data for a study. Validity refers to the ability of a measuring instrument to measure what should be measured (Holmes et al., 2005). On the other hand, reliability refers to the consistency of a measuring instrument to measure a certain concept (Bryman, 2004). According to Mokhtar, Rahman, and Husain (2012), construct validity and reliability testing are conducted for the purpose of strengthening the construct position of a measurement model.

The validity of the measurement model can be measured through construct validity, convergent validity and discriminant validity (Awang, 2015). Construct validity can be achieved when fitness indices meet the acceptance criteria (Afthanorhan, 2013) and the modified measurement model of this study had met all those requirements (see Table 6). Meanwhile, convergent validity is defined as the degree to which a set of indicators of a particular construct converge or share a higher proportion of variance than the norm (Hair, Gabriel, \& Patel, 2014). Evaluation of convergent validity can be performed through examination of the loading factor value, composite reliability (CR) and AVE (Baleghi-Zadeh, Ayub, Mahmud, \& Daud, 2014; Ghadi, Alwi, Bakar, \& Talib, 2012).

Table 7 shows the factor loading values, CR and AVE for the items that remained for the modified measurement model. For the school external protective factors, the AVE value $(0.511>0.50)$ and CR value $(0.935>0.60)$ showed that the items representing three subconstructs, namely caring relationship, high expectations, and meaningful participation under the latent variable fulfilled the convergent validity requirements to measure the school external protective factors. The same was for resilience traits where convergent validity with AVE value of $(0.515>0.50)$ and CR value of $(0.952<0.60)$ were achieved. Hair, Gabriel and Patel $(2014)$ claim that CR values ranging from .82 to .90 are considered excellent. Academic achievement also met the requirements for convergent validity where the AVE value was 0.509 (>0.50) and the CR value was $0.755(>0.60)$.

In addition, discriminant validity was performed to ensure that each construct is different from one another. Discriminant validity is the extent to which the indicators of a construct represent a single construct and the construct's indicators are distinct from other constructs in the model (Hair, Gabriel, \& Patel, 2014). According to Ghadi, Alwi, Bakar and Talib (2012), one of the measurement methods commonly carried out to evaluate discriminant validity is by comparing the AVE value and the squared correlation $\left(r^{2}\right)$ value between the two constructs. Discriminant validity is achieved if the AVE value is higher than the squared correlation $\left(r^{2}\right)$ value of the two constructs involved. Table 8 shows the AVE comparison which is the value located at the corner 
with the $r^{2}$ value of both constructs. The finding shows that both constructs are different from one another and met the discriminant validity conditions.

The reliability of the measurement model can be achieved when the composite reliability (CR) value is $\geq 0.60$ (Hair et al., 2010; Zainuddin, 2013). In addition, the reliability of the measurement model can also be measured through the extracted variance average (AVE) where the AVE value should reach 0.50 and above (Hair et al., 2010). The factor loading, CR and AVE for the latent construct and the items in the modified measurement model as shown in Table 7 have fulfilled the set criteria. Therefore, the modified measurement model in this study has been validated and is reliable. This shows that latent constructs as suggested by Resilience Theory (Benard, 1991) can be explained by the remaining items found in the modified measurement model.

Table 7. Factor Loading, CR, AVE and Items of Modified Measurement Model

\begin{tabular}{|c|c|c|c|c|c|}
\hline Construct & Item & $\begin{array}{c}\text { Factor Loading } \\
(>0.50)\end{array}$ & $\begin{array}{c}\text { CR } \\
(>0.60)\end{array}$ & $\begin{array}{c}\text { AVE } \\
(>0.50)\end{array}$ & Result \\
\hline \multirow[t]{14}{*}{ SEPF } & CR1 & 0.66 & 0.935 & 0.511 & Achieved \\
\hline & CR2 & 0.64 & & & \\
\hline & CR3 & 0.68 & & & \\
\hline & CR4 & 0.68 & & & \\
\hline & CR6 & 0.72 & & & \\
\hline & CR7 & 0.71 & & & \\
\hline & HE10 & 0.76 & & & \\
\hline & HE11 & 0.81 & & & \\
\hline & HE12 & 0.72 & & & \\
\hline & HE13 & 0.63 & & & \\
\hline & MP19 & 0.66 & & & \\
\hline & MP22 & 0.85 & & & \\
\hline & MP23 & 0.80 & & & \\
\hline & MP24 & 0.64 & & & \\
\hline \multirow[t]{14}{*}{ RST } & $\mathrm{CC} 4$ & 0.71 & 0.952 & 0.515 & Achieved \\
\hline & $\mathrm{CC} 6$ & 0.74 & & & \\
\hline & $\mathrm{CC} 7$ & 0.74 & & & \\
\hline & EM10 & 0.83 & & & \\
\hline & EM11 & 0.86 & & & \\
\hline & EM12 & 0.59 & & & \\
\hline & EM15 & 0.57 & & & \\
\hline & PS21 & 0.81 & & & \\
\hline & PS22 & 0.75 & & & \\
\hline & PS23 & 0.68 & & & \\
\hline & SE27 & 0.65 & & & \\
\hline & SE28 & 0.68 & & & \\
\hline & SE30 & 0.70 & & & \\
\hline & SA41 & 0.63 & & & \\
\hline
\end{tabular}


Vol. 8, No. 4, 2019, E-ISSN: 2226-6348 @ 2019 HRMARS

\begin{tabular}{cccccc} 
& SA44 & 0.73 & & & \\
& SA46 & 0.78 & & & \\
& GA48 & 0.72 & & & \\
& GA49 & 0.68 & & & \\
& GA50 & 0.71 & & & \\
& ML 1 & 0.73 & 0.755 & & \\
\hline AA & ML 2 & 0.78 & & & \\
& IE & 0.62 & & & \\
& & & & & \\
& &
\end{tabular}

SEPF: School External Protective Factor; CR: Caring Relationship; HE: High Expectation; MP: Meaningful Participation; RST: Resilience Traits; CC: Cooperation and Communication; EM: Empathy; PS: Problem Solving; SE: Self- Efficacy; SA: Self Awareness; GA: Goals and Aspirations; AA: Academic Achievement; ML 1: Malay Language (Written); ML 2: Malay Language (Oral); IE: Islamic Education.

Table 8. AVE and Squared Correlation between Latent Constructs

\begin{tabular}{llll}
\hline Construct & AA & SEFP & RST \\
\hline AA & $(0.509)$ & & \\
SEFP & 0.063 & $(0.511)$ & \\
RST & 0.04 & 0.423 & $(0.515)$ \\
\hline
\end{tabular}

AA: Academic Achievement; SEPF: School External Protective Factor; RST: Resilience Traits

\section{Conclusion}

Academic resilience helps students from low income families to succeed in academic. There are factors which contributed to academic resilience that are school external protective factor, internal protective factor and resilience traits. Therefore, research on external or internal protective factors are important for better understanding on factors affecting academic achievement among students from low income families. To measure these factors, a validated instrument is required. Hence, the purpose of the study is to validate the proposed measurement model using the confirmatory factor analysis. The constructs of the study, namely school external protective factors, resilience traits and academic achievement were adopted from Resilience Theory by Benard (1991). The findings of the proposed initial measurement model showed a poor fitness value. The modified measurement model achieved good fitness index with the study data. In addition, the modified measurement model also met all the criteria for validity and reliability of a measurement model. Overall, items or observed variables used in this study can measure and validate constructs or latent variables as suggested by Resilience Theory. Therefore, findings from the confirmatory factor analysis revealed that there was a significant relationship between all latent variables such as school external protective factor, resilience traits and academic achievement. In other words, this finding suggests that school external protective factors and resilience traits can influence academic achievement specifically among students from lowincome families in the East Coast of Peninsular Malaysia. This questionnaire is therefore ready for future use by researchers. However, this study recommends that future studies also examine 
INTERNATIONAL JOURNAL OF ACADEMIC RESEARCH IN PROGRESSIVE EDUCATION AND DEVELOPMENT

Vol. 8, No. 4, 2019, E-ISSN: 2226-6348 @ 2019 HRMARS

other external protective factors such as home, peers and the community as suggested by the Resilience Theory.

\section{Acknowledgement}

The researchers would like to express their gratitude to everyone involved in this study, especially the Ministry of Education Malaysia, the State Department of Education, schools, principals, counselors and the students involved for the cooperation given throughout the duration of the study.

\section{Corresponding Author}

Nor Aniza Ahmad (Ph.D), Universiti Putra Malaysia, Malaysia, nor_aniza@upm.edu.my, Department of Foundation Studies, Faculty of Educational Studies, University Putra Malaysia, 43400 UPM Serdang, Selangor, Malaysia.

E-mail: nor_aniza@upm.edu.my

\section{References}

Achour, M., \& Nor, M. R. M. (2014). The effects of social support and resilience on life satisfaction of secondary school students. Journal of academic and applied studies, 4(1), 12-20.

Afthanorhan, W. M. A. B. W. (2013). A comparison of partial least square structural equation modeling (PLS-SEM) and covariance based structural equation modeling (CB-SEM) for confirmatory factor analysis. International Journal of Engineering Science and Innovative Technology, 2(5), 198-205.

Alva, S. A. (1991). Academic invulnerability among Mexican-American students: The importance of protective resources and appraisals. Hispanic Journal of Behavioral Sciences, 13(1), 18-34. doi:10.1177/1056492611432802.

Awang, Z. (2012). Reseach methodology and data analysis. Penerbit Universiti Teknologi MARA Press.

Awang, Z. (2015). SEM made simple: A gentle approach to learning Structural Equation Modeling. MPWS Rich Publication.

Baleghi-Zadeh, S., Ayub, A. F. M., Mahmud, R., \& Daud. S. M. (2014). Behavior intention to use of learning management system among Malaysian pre-service teachers: A confirmatory factor analysis. International Journal of Education and Literacy Studies, 2(1), 29-39.

Banatao, E. J. (2011). Educational Resilience: The Relationship between School Protective Factors and Student Achievement (Unpublished doctoral dissertation). San Diego State University, California.

Benard, B. (1991). Fostering resiliency in kids: Protective factors in the family, school, and community.

Benard, B. (2004). Resiliency What We Have Learned. WestEd.

Bentler, P. M. \& Bonett, D. G. (1980). Significance tests and goodness of fit in the analysis of covariance structures. Psychological Bulletin. 88: 588-606.

Bentler, P.M. (1990). Comparative fit Indexes in structural models. Psychological Bulletin. 107: 238-246.

Brown, M., Cudeck, R. (1993). EQS structural equations program manual. Los Angeles: 
INTERNATIONAL JOURNAL OF ACADEMIC RESEARCH IN PROGRESSIVE EDUCATION AND DEVELOPMENT

Vol. 8, No. 4, 2019, E-ISSN: 2226-6348 @ 2019 HRMARS

Multivariate Software Inc.

Bryant, F. B., \& Yarnold, P. R. (1995). Principal-components analysis and exploratory and confirmatory factor analysis. In L. G. Grimm \& P. R. Yarnold (Eds.), Reading and understanding multivariate statistics (pp. 99-136). Washington, DC, US: American Psychological Association.

Bryman, A. (2004). Social Research Methods (2nd ed.). United State of America: Oxford University Press.

Byrne, B. M. (2010). Structural equation modeling with AMOS: basic concepts, applications, and programming (multivariate applications series). New York: Taylor \& Francis Group, 396, 7384.

Demir, D. K., \& Kalender, I. (2014). Teacher and School-Related Factors that Promote Achievement Differences among Students with Lower Socioeconomic Status. The International Journal of Research in Teacher Education, 5(3), 1-11.

Emmanuel, A. O., Adom, A. E., \& Solomon, F. K. (2014). Perceived stress and academic performance of high school students in Western region, Ghana. European Journal of Business and Social Sciences, 2(11), 88-101.

Finn, J. D., \& Rock, D. A. (1997). Academic success among students at risk for school failure. Journal of applied psychology, 82(2), 221 -234. doi:10.1037/0021-9010.82.2.221.

Ghadi, I., Alwi, N. H., Bakar, K. A., \& Talib, O. (2012). Construct Validity Examination of Critical Thinking Dispositions for Undergraduate Students in University Putra Malaysia. Higher Education Studies, 2(2), 138-145.

Gizir, C. A., \& Aydin, G. (2009). Protective factors contributing to the academic resilience of students living in poverty in Turkey. Professional School Counseling, 13(1), $2156759 \times 0901300103$.

Gonzales, R., \& Padilla, A. M. (1997). The Academic resilience of Mexican American high school students. Hispanic Journal of Behavioral Sciences, 19(3), 301-317. doi:10.1177/07399863970193004

Hair, J. F., Black, W. C., Babin, B. J., \& Anderson, R. E. (2010). Multivariate data analysis (7 ${ }^{\text {th }}$ ed.). New Jersey: Prentice-Hall.

Hair, J. F., Gabriel, M., \& Patel, V. (2014). AMOS covariance-based structural equation modeling (CB-SEM): Guidelines on its application as a marketing research tool. Brazilian Journal of Marketing, 13(2).

Holmes, R., Dahlan, M. H., \& Ashari, H. (2005). A Guide to Research in the Social Sciences. Kuala Lumpur: Prentice Hall, Pearson Malaysia.

Jackson, D., Gillaspy, J., \& Purc-Stephenson, R. (2009). Reporting practices in confirmatory factor analysis: An overview and some recommendations. Psychological Methods, 14 (1), 6-23.

James B. Schreiber, Amaury Nora, Frances K. Stage, Elizabeth A. Barlow \& Jamie King (2006) Reporting Structural Equation Modeling and Confirmatory Factor Analysis Results: A Review, The Journal of Educational Research, 99:6, 323-338, DOI: 10.3200/ JOER.99.6.323-338.

Jennings, G. (2003). An exploration of meaningful participation and caring relationships of contexts for school engagement. The California School Psychologist, 8, 43-52.

Jensen, E. (2009). Teaching with poverty in mind: What being poor does to kids' brains and what schools can do about it. AScD. 
Jowkar, B., Kojuri, J., Kohoulat, N., \& Hayat, A. A. (2014). Academic resilience in education: the role of achievement goal orientations. Journal of Advances in Medical Education \& Professionalism, 2(1), 33.

Luthar, S. S., Cicchetti, D., \& Becker, B. (2000). The construct of resilience: a critical evaluation and guidelines for future work. Society for Research in Child Development, 7 (3), 543-562.

Marsh, H. W., Barnes, J., \& Hocevar, D. (1985). Self- other agreement on multidimensional selfconcept ratings: Factor analysis and multitrait-multimethod analysis. Journal of Personality and Social Psychology, 49(5), 1360.

Masten, A. S. (2001). Ordinary magic: Resilience processes in development. American psychologist, 56(3), 227. doi: 10.1037/0003-066X.56.3.227

Mokhtar, S. B., Rahman, S., \& Husain, M. Y. (2012). Pengesahan Instrumen Persekitaran Pembelajaran : Analisis Faktor Pengesahan. Jurnal Teknologi, 59, 79-85

Nachiappan, S., Osman, R., Masnan, A. H., Mustafa, M. C., Hussein, H., \& Suffian, S. (2019). The Development Of Preschools' Higher Order Thinking Skills (HOTs) Teaching Model towards Improving the Quality of Teaching. International Journal of Academic Research in Progressive Education and Development, 8(2), 39-53.

Niemi, P. M., \& Vainiomäki, P. T. (1999). Medical students' academic distress, coping, and achievement strategies during the preclinical years. Teaching and learning in medicine, 11(3), 125-134. doi 10.1207/S15328015TL110302

Nota, L., Soresi, S., \& Zimmerman, B. J. (2004). Self regulation and academic achievement and resilience: A longitudinal study. International Journal of Educational Research, 41(3), 198215, doi: 10.1016/j.ijer.2005.07.001

Ofori, C.F. Lu, L. (2018). The Evaluation of Internal Audit Functions for Effective Public Sector Administration. A Survey of Accra Metropolitan Assembly, Ghana, International Journal of Academic Research in Accounting, Finance and Management Sciences 8 (2): 19-27.

Schreiber, J. B., Nora, A., Stage, F. K., Barlow, E. A., \& King, J. (2006). Reporting stuctural equation modeling and confirmatory factor analysis results: A review. The Journal of educational research, 99 (6), 323-338.

Schumacker, R. E., \& Lomax, R. G. (2010). A Beginner's Guide to. Structural Equation Modeling $\left(3^{\text {rd }}\right.$ ed). New York, NY: Routledge.

Sharkey, J. D., You, S. \& Schnoebelen, K. (2008). Relations among school assets, individual resilience, and student engagement for youth grouped by level of family functioning. Psychology in the Schools. 45(5): 402-418.

Simon, G. (2012). Building Student Resilience, K-8: Strategies to Overcome Risk and Adversity. Corwin Press.

Wasonga, T. (2002). Gender effects on perceptions of external assets, development of resilience and academic achievement: Perpetuation theory approach. Gender Issues, 20(4), 43-54.

Werner, E. E. (2000). Protective factors and individual resilience. Handbook of early of Childhood Intervention, 2, 115-132

WestEd. (2014). Resilience \& Youth Development Module. Retrieved from www.wested.org/hks

Yasin, M. A. S. M., \& Dzulkifli, M. A. (2011). Differences in depression, anxiety and stress between low-and high achieving students. Journal of Sustainability Science and Management, 6(1), 169-178. 